\title{
Screening of Analgesic, Antimicrobial, Cytotoxic and Antioxidant Activities of Metal Complexes of Indomethacin
}

\author{
Abhijit Sukul ${ }^{1}$, Sreedam Chandra Das ${ }^{2}$, Sajal Kumar Saha² and \\ S.M. Abdur Rahman²
}

${ }^{1}$ Department of Pharmacy, Faculty of Health Sciences, Northern University Bangladesh, Dhaka-1215, Bangladesh

${ }^{2}$ Department of Clinical Pharmacy and Pharmacology, Faculty of Pharmacy, University of Dhaka, Dhaka-1000, Bangladesh

Received: May 21, 2014; Accepted: September 12, 2014; Published (web): December 31, 2014

\begin{abstract}
The present study was performed to evaluate the biological activities of metal complexes of indomethacin with cobalt, copper, manganese and zinc. In radiant tail flick method, complexes of indomethacin with cobalt and copper at a dose of $20 \mathrm{mg} / \mathrm{kg}$ b.w. showed significant central analgesic activity having $66.09 \%$ and $75.45 \%$ elongation of time after 30 minutes and complexes of indomethacin with copper at a dose of $20 \mathrm{mg} / \mathrm{kg}$ b.w. showed significant central analgesic activity having $62.47 \%$ elongation of time after 60 minutes compared to the standard morphine. In this study, indomethacin and its complexes with cobalt, copper and manganese showed mild antimicrobial activity and the indomethacin-manganese complex also displayed highest cytotoxicity with a lowest $\mathrm{LC}_{50} 1.222 \pm 0.21 \mu \mathrm{g} / \mathrm{ml}$ and indomethacin-cobalt, indomethacin-copper and indomethacin-zinc had significant $\mathrm{LC}_{50}$ of $1.549 \pm 0.39 \mu \mathrm{g} / \mathrm{ml}, 1.662 \pm 0.17 \mu \mathrm{g} / \mathrm{ml}$ and $1.903 \pm 0.64 \mu \mathrm{g} / \mathrm{ml}$, respectively where standard vincristine sulphate had $\mathrm{LC}_{50}$ of $0.824 \pm 0.04 \mu \mathrm{g} / \mathrm{ml}$. The complex of indomethacin with cobalt, copper, manganese and zinc revealed \% of inhibition $38.46 \pm 1.03,64.31 \pm 0.21,46.71 \pm 0.46$ and $30.79 \pm 0.30$, respectively and also had significant $\mathrm{IC}_{50}$ of $17.51 \pm 0.62 \mu \mathrm{g} / \mathrm{ml}, 12.31 \pm 0.58 \mu \mathrm{g} / \mathrm{ml}, 15.71 \pm 0.16 \mu \mathrm{g} / \mathrm{ml}$ and 19.84 $\pm 0.08 \mu \mathrm{g} / \mathrm{ml}$ correspondingly. This study indicates that the complexes of indomethacin had analgesic, antimicrobial, cytotoxic and antioxidant activities which could be subjected for further therapeutic evaluation.
\end{abstract}

Key words: Indomethacin, metal complex, radiant tail flick method, central analgesic activity

\section{INTRODUCTION}

NSAIDs are nonsteroidal anti-inflammatory agents which are grouped as a class of drugs that shows antipyretic, analgesic activities and antiinflammatory activities. The necessity of potent and less gastro intestinal damaging agents has led to the synthesis and clinical trial of metal salts of indomethacin. ${ }^{1,2}$

Nonsteroidal anti-inflammatory drugs are most commonly used drugs for the treatment inflammatory diseases such as osteoporosis and arthritis, after having their serious gastrointestinal and cardiovascular toxicity. ${ }^{3,4}$ Indomethacin is readily absorbed

Correspondence to: Sreedam Chandra Das

Tel: +880-2-9661900-73, Extn.- 8156;

Fax: +880-2-9667222; Email: sreedam@du.ac.bd

Dhaka Univ. J. Pharm. Sci. 13(2): 175-180, 2014 (December) with helps to increase in membrane permeability and a rapid reduction in mucosal potential difference. ${ }^{5}$

Nonsteroidal anti-inflammatory drugs can cause damage to the surface-active phospholipids on the mucosal surface. ${ }^{6-10}$ NSAIDs tends to reduce bicarbonate and mucosal secretion which decrease the efficacy of the $\mathrm{pH}$ gradient in epithelial protection. ${ }^{11-13}$

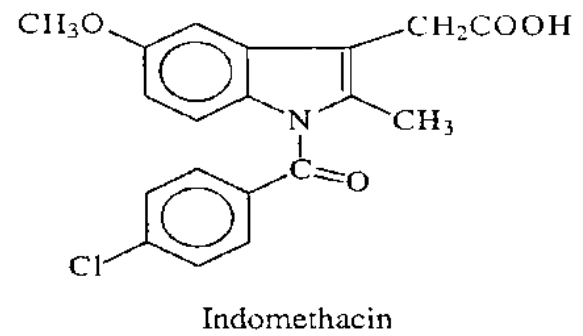


Also there is suppression in prostaglandin levels which cases damage to the gastric mucous layer. ${ }^{14}$ Several trails have been made to reduce the unexpected side effects associated with NSAIDs. Cobalt, copper, manganese and zinc are the d-block elements which may also have the profile of increasing the efficiency of indomethacin in complex form.

So, in this study, we have mentioned about the synthesis and analgesic, antimicrobial, cytotoxic and antioxidant activities of metal complexes of indomethacin with cobalt, copper, manganese and zinc to observe pharmacological activities with good chemical stability.

\section{MATERIALS AND METHODS}

Drugs and materials. Indomethacin was obtained from Ningbo-Smart Pharmaceutical, China. Chemical salts were collected at highest purity from Aristopharma Ltd. and ACI Pharmaceuticals Ltd. Morphine was purchased from Gonoshasthaya Pharmaceuticals Ltd. Vincristine sulfate and ciprofloxacin were collected from Becon Pharmaceuticals Ltd and Square Pharmaceuticals Ltd., respectively.

Solvents and reagents. Dimethyl sulfoxide and sodium bicarbonate were purchased from Merck, Darmstadt, Germany. Acetone, tween-80, methanol and 1, 1-dipheny-1-2-picryl hydrazyl were collected from Sigma Chemicals, USA. Normal saline was obtained from Opsonin Pharma. All chemicals and reagents were of analytical grade.

Synthesis of metal complexes. Indomethacin $1 \mathrm{~g}$ $(0.0028 \mathrm{~mol})$ and acetone $11.2 \mathrm{ml}$ were mixed in a beaker. In the mean while sodium bicarbonate 0.235 $\mathrm{g}(0.0028 \mathrm{~mol})$ was mixed with $11.2 \mathrm{ml}$ of water. The solutions were blended in a beaker and after that another solution of cobalt chloride hexahydrate 0.333 $\mathrm{g}(0.0014 \mathrm{~mol})$ copper sulphate pentahydrate $0.223 \mathrm{~g}$ (0.0014 mol), manganese sulphate monohydrate $0.236 \mathrm{~g}(0.0014 \mathrm{~mol})$ and zinc sulphate heptahydrate $0.226 \mathrm{~g}(0.0014 \mathrm{~mol})$ were prepared in $11.2 \mathrm{ml}$ water and these solutions were mixed separately with indomethacin and sodium bicarbonate mixed solution in different test tubes slowly and stirred continuously. So there pink, green, white and white precipitations were formed consequently. Precipitates were filtered, washed with water and acetone subsequently. At last, it was dried under vacuum condition to get the metal complexes of indomethacin. The yield values were $69.4 \%, 68.9 \%, 65.2 \%$ and $76.5 \%$ of indomethacin complexes with cobalt, copper, manganese and zinc respectively.

Experimental animals. Adult Swiss-albino mice 25-30 g ages of 4-5 week were used as experimental animal. They were housed properly and kept under well controlled temperature with humidity of $60-70 \%$ in the animal house and kept before the test for 5-7 days because of their environmental sensitivity.

Central analgesic activity. Tail flick assay of animal models was used to determine central analgesic response. ${ }^{15} \mathrm{~A}$ hot wire was applied to rat tail, which acted as pain stimulus. When the stimulus exceeded the threshold, rat showed instant withdrawal of its tail. ${ }^{16}$ In this experiment, test samples and saline were administrated orally. Tail flicking time was taken by analgesiometer. For making the wire hot, current was passed through the wire. The animals flick the tail aside the tail. The time of withdrawal of the tail was recorded. Percentage of time elongation was calculated using the following formula: $\%$ elongation of reaction time $=$ Average reaction time of test group - Average reaction time of control group / Average reaction time of control group. The central analgesic activity of the test samples were compared in respect to morphine. Statistical analysis was done using SPSS software by one-way ANOVA considering 95\% confidence level at $p<0.05$ being considered as significant.

Antimicrobial activity. Indomethacin and its complexes were tested for antimicrobial activities by the standardized disc diffusion method. ${ }^{17}$ In vitro antimicrobial screening was done against numerous strains of bacteria and fungi. The obtained results were compared with standard antibiotic, ciprofloxacin. 
Cytotoxic activity. Cytotoxicity was evaluated by using brine shrimp lethality test according to the reported method. ${ }^{18}$ In this test dimethyl sulfoxide and vincristine sulfate were used as negative control and positive control correspondingly. Ten matured shrimps were applied to each of all test tubes of indomethacin and its complexes. After 24 hours the morbidity of brine shrimps was observed. An approximate linear correlation was observed by plotting logarithm of concentration versus percentage of mortality.

Antioxidant activity. The antioxidant activity of indomethacin and its complexes was assessed by 1 , 1-dipheny-1-2-picryldrazyl and estimated by reported methods. ${ }^{19}$ Here butylated hydroxyl toluene was used as standards and DPPH solution was used as control.

The absorbance was measured by UV spectrophotometer at a wave length of $570 \mathrm{~nm}$. Inhibition of free radical was estimated by following equation:

Inhibition of free radical $\%=A_{c}-A_{s} / A_{c} \times 100$ where, $\mathrm{A}_{\mathrm{c}}=$ Absorbance of the control and $\mathrm{A}_{\mathrm{s}}=$ Absorbance of the indomethacin and its complexes. The $50 \%$ inhibitory concentration $\mathrm{IC}_{50}$ was calculated by plotting the inhibition concentration versus standard indomethacin complex concentration.

Statistical analysis. Statistical analyses were done by using the Statistical Package for Social Science version 16.0 software, and statistical differences between groups were analyzed by one- way analysis of variance ANOVA followed by Dunnet's t-tests. Data's were represented as means \pm SEM and differences were considered statistically significant at $p<0.05$.

\section{RESULTS AND DISCUSSION}

Central analgesic activity. The central analgesic activities of metal complexes of indomethacin in tail flick method are given in Table 1. In this experiment, metal complexes were given at a dose of $10 \mathrm{mg} / \mathrm{kg}$ b.w. and $20 \mathrm{mg} / \mathrm{kg}$ b.w. individually. Complexes of indomethacin with cobalt and copper at a dose of 20 $\mathrm{mg} / \mathrm{kg}$ b.w. showed significant analgesic activity having $66.09 \%$ and $75.45 \%$ elongation of reaction time and complexes of indomethacin with manganese and zinc at a dose of $20 \mathrm{mg} / \mathrm{kg}$ b.w. showed significant analgesic activity having $38.78 \%$ and $38.89 \%$ elongation of reaction time, respectively at 30 minutes compared to the standard morphine $132.52 \%$, where indomethacin at a dose of $10 \mathrm{mg} / \mathrm{kg}$ b.w. showed the least elongation reaction time $14.67 \%$. At 60 minutes, for the complexes of indomethacin with cobalt, copper, manganese and zinc at a dose of $20 \mathrm{mg} / \mathrm{kg}$ b.w., increased the tail flicking time by $42.52 \%, 62.47 \%, 31.79 \%$ and $33.11 \%$ subsequently and after 90 minutes, the central analgesic activity gradually decreases except the complex of indomethacin with copper at a dose of $20 \mathrm{mg} / \mathrm{kg}$ b.w. which showed significant analgesic activity of $37.18 \%$.

Table 1. Central analgesic activity of indomethacin and its metal complexes.

\begin{tabular}{|c|c|c|c|c|}
\hline \multirow[t]{2}{*}{ Groups } & \multirow{2}{*}{$\begin{array}{c}\text { Dose } \\
\mathrm{mg} / \mathrm{kg} \text { b.w. }\end{array}$} & \multicolumn{3}{|c|}{ Reaction time sec } \\
\hline & & $\begin{array}{l}\% \text { elongation } \\
30 \mathrm{~min}\end{array}$ & $\begin{array}{l}\% \text { elongation } \\
60 \mathrm{~min}\end{array}$ & $\begin{array}{l}\% \text { elongation } \\
90 \text { min }\end{array}$ \\
\hline Control & - & $9.41 \pm 0.38$ & $8.82 \pm 0.83$ & $8.15 \pm 0.38$ \\
\hline Standard & 2 & $21.88 \pm 0.41,132.52^{* * * *}$ & $19.18 \pm 0.48,117.46^{* * *}$ & $16.8 \pm 0.85,106.13^{* * *}$ \\
\hline \multirow[t]{2}{*}{ Indomethacin } & 10 & $10.79 \pm 1.10,14.67$ & $9.82 \pm 1.30,11.33$ & $8.93 \pm 0.91,9.57$ \\
\hline & 20 & $11.46 \pm 0.51,21.79$ & $10.38 \pm 0.76,17.68$ & $9.27 \pm 0.11,13.74$ \\
\hline \multirow{2}{*}{ Indomethacin-cobalt } & 10 & $10.91 \pm 1.22,15.94$ & $9.92 \pm 0.92,12.47$ & $9.07 \pm 0.49,11.29$ \\
\hline & 20 & $15.33 \pm 0.93,66.09^{* * *}$ & $12.57 \pm 1.39,42.52^{* *}$ & $10.51 \pm 0.67,28.96^{*}$ \\
\hline \multirow[t]{2}{*}{ Indomethacin-copper } & 10 & $12.29 \pm 0.59,30.61 *$ & $10.86 \pm 1.60,23.13$ & $9.91 \pm 0.52,21.59$ \\
\hline & 20 & $16.51 \pm 0.19,75.45^{* * * *}$ & $14.33 \pm 0.35,62.47^{* * *}$ & $11.18 \pm 0.30,37.18 * *$ \\
\hline \multirow[t]{2}{*}{ Indomethacin-manganese } & 10 & $11.06 \pm 0.47,17.53$ & $10.33 \pm 0.84,17.12$ & $9.67 \pm 0.62,18.65$ \\
\hline & 20 & $13.06 \pm 1.01,38.78 * *$ & $11.57 \pm 0.51,31.79^{* *}$ & $10.72 \pm 0.59,29.69^{*}$ \\
\hline \multirow[t]{2}{*}{ Indomethacin-zinc } & 10 & $11.54 \pm 0.83,22.32$ & $9.51 \pm 0.44,7.82$ & $8.62 \pm 0.21,5.77$ \\
\hline & 20 & $13.07 \pm 1.15,38.89^{* *}$ & $11.74 \pm 1.37,33.11^{* *}$ & $10.50 \pm 0.29,28.83^{*}$ \\
\hline
\end{tabular}

Each value expressed as the mean \pm SEM. Significant at $* * * p<0.001, * * p<0.01, * p<0.05$ compared to control group. 
Table 2. Antimicrobial activity of indomethacin and its metal complexes.

\begin{tabular}{|c|c|c|c|c|c|c|}
\hline \multirow[t]{2}{*}{ Test organism } & \multicolumn{4}{|c|}{ Zone of inhibition in $\mathrm{mm}$} & \multirow[b]{2}{*}{ IM } & \multirow[b]{2}{*}{$\mathrm{IZ}$} \\
\hline & CIP & $\mathrm{I}$ & $\mathrm{ICO}$ & $\mathrm{IC}$ & & \\
\hline \multicolumn{7}{|l|}{ Gram Positive bacteria } \\
\hline Bacillus cereus & 44 & 9 & 7 & 9 & 8 & - \\
\hline Bacillus megaterium & 44 & 9 & 7 & 8 & 8 & - \\
\hline Bacillus subtilis & 44 & 10 & 7 & 8 & 8 & - \\
\hline Sarcina lutea & 45 & 9 & 7 & 8 & 8 & - \\
\hline Staphylococcus aureus & 44 & 9 & 7 & 8 & 8 & - \\
\hline \multicolumn{7}{|l|}{ Gram Negative bacteria } \\
\hline Escherichia coli & 44 & 9 & 7 & 8 & 8 & - \\
\hline Pseudomonas aeruginosa & 44 & 9 & 7 & 8 & 8 & - \\
\hline Salmonella paratyphi & 45 & 9 & 7 & 8 & 8 & - \\
\hline Salmonella typhi & 45 & 9 & 7 & 8 & 8 & - \\
\hline Vibrio parahaemolyticus & 45 & 9 & 7 & 8 & 8 & - \\
\hline Shigella boydii & 44 & 9 & 7 & 8 & 8 & - \\
\hline Shigella dysenteriae & 44 & 9 & 7 & 8 & 8 & - \\
\hline Vibrio mimicus & 44 & 9 & 7 & 8 & 8 & - \\
\hline \multicolumn{7}{|l|}{ Fungi } \\
\hline Candida albicans & 45 & 9 & 7 & 8 & 8 & - \\
\hline Aspergillus niger & 46 & 9 & 7 & 8 & 8 & - \\
\hline Sacharomyces cerevacae & 45 & 9 & 7 & 8 & 8 & - \\
\hline
\end{tabular}

$\mathrm{CIP}=$ ciprofloxacin $; \mathrm{I}=$ indomethacin $; \mathrm{ICO}=$ indomethacin-cobalt $; \mathrm{IC}=$ indomethacin-copper; $\mathrm{IM}=$ indomethacin-manganese; $\mathrm{IZ}=$ indomethacin-zinc.

Table 3. Cytotoxic activity of indomethacin and its complexes.

\begin{tabular}{ll}
\hline \multicolumn{1}{c}{ Test samples } & $\mathrm{LC}_{50} \mu \mathrm{g} / \mathrm{ml}$ \\
\hline Vincristine Sulphate & $0.824 \pm 0.04$ \\
Indomethacin & $1.542 \pm 0.13^{* * *}$ \\
Indomethacin-cobalt & $1.549 \pm 0.39^{* * *}$ \\
Indomethacin-copper & $1.662 \pm 0.17 * * *$ \\
Indomethacin-manganese & $1.222 \pm 0.21^{* * *}$ \\
Indomethacin-zinc & $1.903 \pm 0.64 * * *$ \\
\hline
\end{tabular}

Data of $\mathrm{LC}_{50}$ represents mean $\pm \mathrm{SEM}$ of triplicate analysis and significant at $* * * p<0.001$ compared to vincristine sulphate.

Table 4. Antioxidant activity of indomethacin and its metal complexes.

\begin{tabular}{lll}
\hline Samples & \% of Inhibition & $\begin{array}{l}\text { Free radical scavenging } \\
\text { activity } \mathrm{IC}_{50} \\
\mu \mathrm{g} / \mathrm{ml}\end{array}$ \\
\hline BHT & $66.47 \pm 0.14$ & $11.45 \pm 0.53$ \\
Indomethacin & $28.51 \pm 0.39$ & $21.73 \pm 0.64$ \\
Indomethacin-cobalt & $38.46 \pm 1.03^{* *}$ & $17.51 \pm 0.62^{* *}$ \\
Indomethacin-copper & $64.31 \pm 0.21^{* * *}$ & $12.31 \pm 0.58^{* * *}$ \\
Indomethacin-manganese & $46.71 \pm 0.46^{* * *}$ & $15.71 \pm 0.16^{* * *}$ \\
Indomethacin-zinc & $30.79 \pm 0.30^{* * *}$ & $19.84 \pm 0.08^{* * *}$ \\
\hline
\end{tabular}

Values are expressed as the mean \pm SEM of triplicate analysis and significant at $* * * p<0.001, * * p<0.01, * p<0.05$ compared to standard BHT.

Antimicrobial activity. To determine antimicrobial activity of metal complexes of indomethacin were tested against some gram positive and some gram negative bacteria. Here, five gram positive bacteria namely, B. cereus, B. megaterium,
B. subtilis, S. lutea and Stap. aureus as well as eight gram negative bacteria namely, $E$. coli, $P$. aeruginosa, S. paratyphi, V. mimicus, S. dysenteriae and also three fungi namely, C. albicans, A. niger and S. cerevacae were used (Table 2). In this study, 
indomethacin and its complexes showed mild to moderate antimicrobial activity except zinc complex of indomethacin. The zone of inhibition for indomethacin, indomethacin-cobalt, indomethacincopper and indomethacin-manganese were $9-10 \mathrm{~mm}$, $7 \mathrm{~mm}, 8-9 \mathrm{~mm}$ and $8 \mathrm{~mm}$ respectively which was compared to standard ciprofloxacin with an inhibition zone of $44-45 \mathrm{~mm}$ as mentioned in Table 2 .

Cytotoxic activity. The results obtained from brine shrimp lethality assay are presented in Table 3. The $\mathrm{LC}_{50}$ denoted the concentration by which $50 \%$ of shrimps were killed. Here, indomethacin manganese complex showed the highest cytotoxicity with a lowest value of $\mathrm{LC}_{50} 1.222 \pm 0.21 \mu \mathrm{g} / \mathrm{ml}$. The positive control appeared to have a $\mathrm{LC}_{50}$ of $0.824 \pm$ $0.04 \mu \mathrm{g} / \mathrm{ml}$. As well as, indomethacin, indomethacincobalt, indomethacin-copper and indomethacin-zinc had a $\mathrm{LC}_{50}$ of $1.542 \pm 0.13 \mu \mathrm{g} / \mathrm{ml}, 1.549 \pm 0.39$ $\mu \mathrm{g} / \mathrm{ml}, 1.662 \pm 0.17 \mu \mathrm{g} / \mathrm{ml}$ and $1.903 \pm 0.64 \mu \mathrm{g} / \mathrm{ml}$ correspondingly.

Antioxidant activity. The antioxidant activity of indomethacin and its complexes are shown in Table 4. Complex of indomethacin with cobalt, copper, manganese and zinc showed \% of inhibition $38.46 \pm$ $1.03,64.31 \pm 0.21,46.71 \pm 0.46$ and $30.79 \pm 0.30$, respectively. In addition, complex of indomethacin with cobalt, copper, manganese and zinc were tested against for the evaluation of free radical scavenging capacity compared to tert-butyl-1-hydroxytoluene as standard. In this case, complex of indomethacin with cobalt, copper, manganese and zinc showed free radical scavenging activity having significant $\mathrm{IC}_{50}$ of $17.51 \pm 0.62 \mu \mathrm{g} / \mathrm{ml}, 12.31 \pm 0.58 \mu \mathrm{g} / \mathrm{ml}, 15.71 \pm 0.16$ $\mu \mathrm{g} / \mathrm{ml}$ and $19.84 \pm 0.08 \mu \mathrm{g} / \mathrm{ml}$, respectively.

\section{CONCLUSION}

Therefore, it can be concluded from the present studies that cobalt and manganese complexes of indomethacin showed strong central analgesic activity and copper and manganese complexes of indomethacin also showed significant antioxidant activity. In case of antimicrobial and cytotoxicity screening mild activities were observed. So, further studies will be focused on the other biological activities of the metal complexes.

\section{ACKNOWLEDGEMENT}

Authors wish to thank Mr. Zobaer Al Mahmud, Assistant Professor, Department of Clinical Pharmacy and Pharmacology, University of Dhaka for providing his support to our research work.

\section{REFERENCES}

1. Weser, U., Sellinger, K.H., Lengfelder, E., Werner, W. and Strahle. J. 1980. Biochem. Biophys. Acta. 631, 232-242.

2. Harris, E.D., DiSilvestro, R.A., Balthrop, J.E. and Sorenson J.R.J. 1982. Inflammatory diseases and copper. Experimental Biology and Medicine Series. Vol. 2, p. 183-198. New Jerssy: Springer/Human Press.

3. Grosser, T., Fries, S. and FitzGerald, G.A. 2006. Biological basis for the cardiovascular consequences of COX-2 inhibition: therapeutic challenges and opportunities. J. Clin. Invest. 116, 4-15.

4. Wallace, J.L. 2008. Prostaglandins, NSAIDs, and gastric mucosal protection: why doesn't the stomach digest itself? Physiol Rev. 88, 1547-1565.

5. Price, A.H. and Fletcher, M. 1990. Mechanisms of NSAIDinduced gastro-enteropathy. Drugs Suppl. 5. 40,1-11.

6. Lichtenberger, L.M., Zhou, Y., Dial, E.J. and Raphael, R.M. 2006. NSAID injury to the gastrointestinal tract: evidence that NSAIDs interact with phospholipids to weaken the hydrophobic surface barrier and induce the formation of unstable pores in membranes. J. Pharm. Pharmacol. 58, 1421-1428.

7. Lichtenberger, L.M., Romero, J.J. and Dial, E.J. 2007. Surface phospholipids in gastric injury and protection when a selective cyclooxygenase-2 inhibitor Coxib is used in combination with aspirin. Br. J. Pharmacol. 150, 913-920.

8. Darling, R.L., Romero, J.J., Dial, E.J., Akunda, J.K., Langenbach, R. and Lichtenberger, L.M. 2004. The effects of aspirin on gastric mucosal integrity, surface hydrophobicity and prostaglandin metabolism in cyclooxygenase knockout mice. Gastroenterology 127, 94-104.

9. Lichtenberger, L.M., Zhou, Y., Dial, E.J. and Raphael, R.M. 2006. NSAID injury to the gastrointestinal tract: evidence that NSAIDs interact with phospholipids to weaken the hydrophobic surface barrier and induce the formation of unstable pores in membranes. J. Pharm. Pharmacol. 58, 1421-1428.

10. Giraud, M.N., Motta, C., Romero, J.J., Bommelaer, G. and Lichtenberger, L.M. 1999. Interaction of indomethacin and naproxen with gastric surface active phospholipids: a possible mechanism for the gastric toxicity of nonsteroidal antiinflammatory drugs. Biochem. Pharmacol. 57, 247-254. 
11. Atuma, C., Strugala, V., Allen, A. and Holm, L. 2001. The adherent gastrointestinal mucus gel layer: thickness and physical state in vivo. Am. J. Physiol. Gastrointest. Liver Physiol. 280, 922-929.

12. Brzozowska, I., Targosz, A., Sliwowski, Z., Kwiecien, S., Drozdowicz, D., Pajdo, R., Konturek, P.C., Brzozowski, T., Pawlik, M., Konturek, S.J., Pawlik, W.W. and Hahn, E.G. 2004. Healing of chronic gastric ulcers in diabetic rats treated with native aspirin, nitric oxide derivative of aspirin and COX-2 inhibitor. J. Physiol. Pharmacl. 55, 773-790.

13. Jaworski, T., Sarosiek, I., Sostarich, S., Roeser, K., Connor, M., Brotze, S., Wallner, G. and Sarosiek, J. 2005. Restorative impact of rabeprazoleon gastric mucus and mucin production impairment during naproxen administration: its potential clinical significance. Dig. Dis. Sci. 50, 357-365.

14. Rainsford, K.D. and Willis, C. 1982. Relationship of gastric mucosal damage induced in pigs by anti-inflammatory drugs to their effects on prostaglandin production. Dig. Dis. Sci. 27, 624-635.
15. Pizziketti, R.J., Pressman, N.S., Geller, E.B., Cowan, A and Adler, M.W. 1985. Rat cold water tail-flick: a novel analgesic test that distinguishes opioid agonists from mixed agonistantagonists. Eur. J. Pharmacol. 119, 23-29.

16. Ahmed, F., Selim, M.S.T., Das, A.K. and Choudhuri, M.S.K. 2004. Anti-inflammatory and antinociceptive activities of Lippia nodiflora. Pharmazie 59, 329-333.

17. Bauer, A.W., Kirby, W.M., Sherries, J.C. and Tuck, M. 1966. Antibiotic susceptibility testing by a standardized disc diffusion method. J. Am. Clin. Pathol. 45, 493-496.

18. Meyer, B.N., Ferringni N.R., Puam, J.E., Lacobsen, L.B., Nichols, D.E. and McLaughlin, J.L. 1982. Brine shrimp: a convenient general bioassay for active constituents. Planta. Med. 45, 31-32.

19. Brand-Williams, W., Cuvelier, M.E. and Berset, C. 1995. Use of a free radical method to evaluate antioxidant activity. $L W T$ - Food Sci. Technol. 28, 25-30. 